\title{
Impaired Nociception and Inflammatory Pain Sensation in Mice Lacking the Prokineticin Receptor PKR1: Focus on Interaction between PKR1 and the Capsaicin Receptor TRPV1 in Pain Behavior
}

\author{
Lucia Negri, ${ }^{1}$ Roberta Lattanzi, ${ }^{1}$ Elisa Giannini, ${ }^{1}$ Mariantonella Colucci, ${ }^{1}$ Federica Margheriti, ${ }^{1}$ Pietro Melchiorri, ${ }^{1}$ \\ Vittorio Vellani, ${ }^{2}$ Hui Tian, ${ }^{3}$ Milena De Felice, ${ }^{1,4}$ and Frank Porreca ${ }^{4}$ \\ ${ }^{1}$ Department of Human Physiology and Pharmacology "Vittorio Erspamer", University of Roma "La Sapienza”, 00185 Roma, Italy, ${ }^{2}$ Department of \\ Biomedical Sciences, University of Modena and Reggio Emilia, 41100 Modena, Italy, ${ }^{3}$ Amgen, South San Francisco, California 94080, and ${ }^{4}$ University of \\ Arizona, Tucson, Arizona 58274
}

\begin{abstract}
Bv8, prokineticin-1 or EG-VEGF (endocrine gland-derived vascular endothelial growth factor), and prokineticin-2, are naturally occurring peptide agonists of two G-protein-coupled receptors (GPCRs), prokineticin receptor 1 (PKR1) and PKR2. PKRs are expressed in neurons in the CNS and peripheral nervous system and many dorsal root ganglion (DRG) cells expressing PKRs also express transient receptor potential vanilloid receptor-1 (TRPV1). Mice lacking the pkr1 gene were generated to explore the role of the PKR1 receptor in nociceptive signaling and in nociceptor sensitization. When compared with wild-type littermates, mice lacking the pkr1 gene showed impaired responsiveness to noxious heat, mechanical stimuli, capsaicin, and protons. In wild-type mice, activation of PKRs by the PKR agonist Bv8 caused hyperalgesia and sensitized to the actions of capsaicin. pkr1-null mice exhibited impaired responses to Bv8 but showed normal hyperalgesic responses to bradykinin and PGE2 (prostaglandin E2). Conversely, trpv1-null mice showed a reduced pronociceptive response to Bv8. Additionally, pkr1-null mice showed diminished thermal hyperalgesia after acute inflammation elicited by mustard oil and reduced pain behavior after chronic inflammation produced by complete Freund's adjuvant. The number of neurons that responded with a $\left[\mathrm{Ca}^{2+}\right]_{\mathrm{i}}$ increase to Bv8 exposure was five times lower in pkr1-null DRG cultures than in wild-type cultures. Furthermore, Bv8-responsive neurons from pkr1-null mice showed a significant reduction in the $\left[\mathrm{Ca}^{2+}\right]_{\mathrm{i}}$ response to capsaicin. These findings indicate a modulatory role of PKR1 in acute nociception and inflammatory pain and disclose a pharmacological interaction between PKR1 and TRPV1 in nociceptor activation and sensitization.
\end{abstract}

Key words: PKR1; TRPV1; prokineticins; Bv8; nociception; inflammation

\section{Introduction}

Our understanding of the cellular and molecular basis underlying nociception has increased dramatically in recent years. A number of receptors and ion channels important in nociception have recently been cloned. Notable examples include two G-proteincoupled receptors for bradykinin (Pesquero et al., 1994); the acid-sensing ion channel family (ASIC) (Waldmann et al., 1997); ATP-sensing ion channels of the P2X family (Chen et al., 1995; Lewis et al., 1995; Chessel et al., 2005); nociceptor-specific TTXinsensitive $\mathrm{Na}$ channels $\left(\mathrm{Na}_{\mathrm{v}} 1.8\right.$ and $\left.\mathrm{Na}_{\mathrm{v}} 1.9\right)$ (Akopian et al., 1996; Dib-Hajj et al., 2002); and the vanilloid receptor TRPV1, which belongs to the transient receptor potential (TRP) super-

Received Dec. 19, 2005; revised May 13, 2006; accepted May 13, 2006.

This work was supported by grants from the Italian Ministry of Education, University and Scientific Research (PRIN 2004057339; PRIN 2004037781; FIRB Prot. RBAU01TEBF), the University of Rome La Sapienza (Ateneo Projects 2004 -2005), and by Fondazione Cassa di Risparmio di Modena and Fondazione Cassa di Risparmio di Carpi (V.V.).

Correspondence should be addressed to Lucia Negri, Department of Human Physiology and Pharmacology, University of Roma "La Sapienza”, Piazzale Aldo Moro 5, 00185 Rome, Italy. E-mail: lucia.negri@uniroma1.it.

D01:10.1523/JNEUROSCI.5403-05.2006

Copyright $\odot 2006$ Society for Neuroscience $\quad$ 0270-6474/06/266716-12\$15.00/0 family and is potently activated by capsaicin (Caterina et al., 1997, 2000).

An important property of pain signaling is that of sensitization. In the wake of even quite modest noxious stimuli, the threshold to elicit pain is reduced, and the pain associated with suprathreshold stimuli is augmented. Painful stimuli can induce central (spinal and supraspinal) and peripheral (nociceptor) sensitization. Both types of sensitization operate in inflammatory diseases, the single greatest cause of chronic pain. Many extracellular pain mediators such as prostaglandins, bradykinin, serotonin, adenosine, neurotrophins, ATP, proteinases, chemokine, and others have been shown to elicit peripheral nociceptor sensitization through the activation of receptors at nociceptor terminals (McMahon et al., 2006). The recently cloned prokineticin receptors, prokineticin receptor 1 (PKR1) and PKR2 (Lin et al., 2002), and their activation by peptides belonging to the Bv8/EGVEGF (endocrine gland-derived vascular endothelial growth factor)-PK (prokineticin) family suggest an additional novel mechanism of peripheral nociceptor activation and sensitization (Negri et al., 2002). 
PKs are small secreted proteins $(8-11 \mathrm{kDa})$ (Mollay et al., 1999; Wechselberger et al., 1999; LeCouter et al., 2001; Li et al., 2001) that lower the nociceptor threshold to a broad spectrum of physical and chemical stimuli (Negri et al., 2002). In primary cultures of rat DRG neurons, Bv8 binds and activates PKRs, producing an increase in $\left[\mathrm{Ca}^{2+}\right]_{\mathrm{i}}$. Although these studies suggest that activation of PKRs can elicit nociception and nociceptor sensitization, whether these receptors might contribute to nociceptor sensitivity to thermal, mechanical, or chemical stimuli in vivo is unknown, primarily the result of a lack of receptor selective antagonists.

The present study used a genetic strategy to determine whether PKR1 expression is important in determining sensory thresholds to nociceptive and to acute and chronic inflammatory stimuli. PKR1-null mutant mice were generated and used to investigate nociceptive responses to noxious heat, mechanical stimuli, intraperitoneal acetic acid, and intraplantar and oral capsaicin. Additionally, the development of Bv8-, bradykinin-, and prostaglandin E2 (PGE2)-induced nociceptor sensitization as well as hyperalgesia to acute and chronic inflammatory stimuli were investigated in PKR1 knock-out (KO) mice. Considering that PKR1 is a G-protein-coupled metabotropic receptor (Lin et al., 2002) and that similar signaling receptors such as ATP, bradykinin, and proteinase-activated and chemokine receptors sensitize the vanilloid receptor TRPV1 to noxious stimuli (Tominaga et al., 2001; Sugiura et al., 2002; Dai et al., 2004; Zhang et al., 2005), we examined whether a positive co-operativity between the PKR1 prokineticin receptor and the TRPV1 channel contributes to acute nociception and pain behavior.

\section{Materials and Methods}

pkr1-null mutant mice. $\mathrm{pkr}^{-1-}$ mice were generated by Lexicon Genetics (The Woodlands, TX). To generate pkr1-deficient mice, a targeting vector was constructed in which exon 1 of the PKR1 gene was replaced with a neomycin resistance gene derived from MC1 neo vector. Lex-1 embryonic stem cells were electroporated with the targeting vector before selection of the cells expressing the targeted allele for the generation of chimeric mice. Germline chimeras were crossed with C57BL/6J females to generate heterozygotes and then intercrossed, giving rise to overtly healthy mutant offspring in the expected Mendelian ratio. Successful targeting and transmission was confirmed by Southern and Western blot analysis. Progeny were genotyped with PCR, which permitted the amplification of the wild-type (WT) pkrl gene (primers: 5'GGTGACTATGACATGCCCCTGG-3' and 5'-CTCTCGGAAAGGGAGAGGCAAGG-3') and the neomycin cassette, which was inserted to disrupt PKR1 coding region (primers: 5'GCAGCGCATCGCCTTCTATC- $3^{\prime}$ and $5^{\prime}$-CTCTCGGAAAGGGAGAGGCAAGG- $3^{\prime}$ ). Genomic DNA was isolated from tail samples by proteinase K (Sigma, St. Louis, MO) digestion and ethanol precipitation, and $200 \mathrm{ng}$ of DNA was amplified (HotStarTaq DNA Polymerase; Qiagen, Milan, Italy) with the following cycle parameters: $95^{\circ} \mathrm{C}$ for $3 \mathrm{~min}(1 \mathrm{cycle}) ; 95^{\circ} \mathrm{C}$ for $1 \mathrm{~min}, 55^{\circ} \mathrm{C}$ for $1 \mathrm{~min}, 72^{\circ} \mathrm{C}$ for $1 \mathrm{~min}(30$ cycles $) ; 72^{\circ} \mathrm{C}$ for $10 \mathrm{~min}$ ( 1 cycle). Amplified products were separated by $2 \%$ agarose gel electrophoresis and stained with ethidium bromide, and the resulting fluorescent bands were revealed with the Versa Doc 3000 imaging system (Bio-Rad, Milan, Italy) (see Fig. $2 A$ ). $\mathrm{pkr1}^{-/-}$mice were viable and largely indistinguishable from wild-type littermates.

Measurements of acute nociception. Nociceptive responses to noxious stimuli including heat, punctate stimuli, protons, and capsaicin were measured in wild-type and pkr1-null mutant mice. For each nociceptive test and drug dose, a different group of male mice from each genotype was used. Each mouse was used only once and immediately killed by $\mathrm{CO}_{2}$ after the experiment ended. All experiments were performed under protocols approved by the Animal Care and Use Committee of the Italian Ministry of Health according to European Community directives.

The nociceptive threshold to heat was measured with the tail-flick test, the hot-plate test, the Hargreaves' test of paw withdrawal, and by briefly immersing the mouse tail or hindpaw into hot water. For the tail-flick test, a light beam was focused on the tail tip, and the latency to tail withdrawal was taken as a measure of tail nociceptive threshold to radiant heat (D'Amour and Smith, 1941). For the Hargreaves' test, Basile Plantar test apparatus (Ugo Basile, Comerio, Italy) was used. A light beam was focused on the plantar region of mouse hindpaws, and the latency to paw withdrawal was recorded and taken as a measure of paw nociceptive threshold to radiant heat (Hargreaves et al., 1988). The hot-plate test was done in a microprocessor-controlled unit (catalog \#7280; Ugo Basile) at plate temperatures ranging from 46 to $51^{\circ} \mathrm{C}$. Tail and paw immersion tests were performed by dipping one third of the mouse tail or one hindpaw into hot $\left(46,48\right.$, and $\left.51^{\circ} \mathrm{C}\right)$ water and measuring the latencies to tail or paw withdrawal.

To assess the tactile threshold to punctate stimuli, von Frey filaments were applied to the skin of mouse plantar surface, and the threshold force at which $50 \%$ of mice withdrew their paws was determined using the up-down method (Chaplan et al., 1994)

Nociceptive behaviors to noxious chemical agents were evaluated in both mouse genotypes using the abdominal writhing after intraperitoneal injection of dilute acetic acid, the paw-licking test after intrapaw capsaicin and bradykinin and the aversive drinking test by adding capsaicin to drinking water.

For the abdominal writhing test, intraperitoneal injection of dilute acetic acid [ $5 \mu \mathrm{l} / \mathrm{g}$ body weight (b.w.) of $0.8 \%$ acetic acid solution] was used to induce nociceptive stereotyped behavior (Koster et al., 1959). The intensity of pain evoked in both mouse genotypes was measured by counting the number of abdominal cramps occurring during the $20 \mathrm{~min}$ observation period. Paw licking (Ferreira et al., 2004) was evoked by injecting graded doses of capsaicin (from 0.05 to $5 \mathrm{nmol}$ ) or 5 and $50 \mu \mathrm{g}$ of bradykinin into the plantar skin of one hindpaw, and the elicited nociceptive behavior was recorded with a television camera and videotape recorder. The duration of the nociceptive behavior and the number of paw licking and shaking events were measured using a computer and the Observer software (Noldus Information Technology, Wageningen, The Netherlands). Trigeminal nociception was assessed with an aversive drinking test to capsaicin (Caterina et al., 2000). For 4 d, mice were allowed to drink for $3 \mathrm{~h} / \mathrm{d}$ from a bottle containing $0.125 \%$ saccharine in water. On the fifth day, this solution was supplemented with five capsaicin concentrations $(10,20,30,50,100 \mu \mathrm{M})$, and each concentration was presented to six wild-type and six $\mathrm{pkr}^{-1-}$ mice. For each capsaicin concentration, the volume of capsaicin solution ingested by $\mathrm{pkr}^{-1-}$ mice was compared with that ingested by wild-type mice.

Measurement of nociceptive sensitization. Possible nociceptive sensitization induced by proalgesic agents such as Bv8, PGE2, bradykinin, and capsaicin or resulting from acute and chronic hindpaw inflammation was measured by determining changes in response thresholds to noxious or non-noxious sensory stimuli in wild-type and pkr1-null mutant mice.

To measure thermal hyperalgesia, the tail-flick, the hot-plate, and paw immersion in hot water tests were used. In both genotypes, systemic Bv8-induced hyperalgesia was elicited by injecting Bv8 subcutaneously in doses ranging from 1 to $100 \mu \mathrm{g} / \mathrm{kg}$. To evaluate Bv8-induced topical hyperalgesia, $\mathrm{pkr1}^{-1-}$ and $\mathrm{pkr1}^{+/+}$mice were injected into the plantar region of hindpaws with graded doses of Bv8 (from 0.1 to $5 \mathrm{ng} / \mathrm{paw}$ ). Capsaicin-, PGE2-, and bradykinin-induced thermal hyperalgesia was elicited by injecting capsaicin $(12 \mu \mathrm{g})$, PGE2 $(0.5-1 \mu \mathrm{g})$, or bradykinin ( 2 $\mu \mathrm{g})$ into the hindpaws of wild-type and pkr1-null mice.

To measure Bv8-induced tactile hyperalgesia, von Frey filaments were used, as described previously under tactile threshold measurement.

Pain behavior showed by differences in the pattern of body weight distribution between the two hindpaws was assessed in mice using a weight-bearing averager (incapacitance tester; MJS Technology, Stevenage Hertz, UK), as described by Chessel et al. (2005). In brief, mice were placed in a Plexiglas container, which restricted their movement. The middle portion of the floor consisted of two independent force plates, which measured the weight borne by the left and right hindlimbs, respectively. Body weight borne by saline-injected right hindpaw and Bv8- or capsaicin-injected left hindpaw was averaged over $30 \mathrm{~s}$ and expressed as right/left percentage weight difference. 
Bv8 $(0.5 \mathrm{ng} / 20 \mu \mathrm{l})$ was injected into one of the two hindpaws of wildtype and pkr1-null mice and 15, 30, 45, 60, and $120 \mathrm{~min}$ after the injection, hypersensitivity to von Frey filaments or to body weight bearing was evaluated.

To evaluate the time course of Bv8-induced sensitization to capsaicininduced licking, capsaicin $(0.01 \mathrm{nmol} / 20 \mu \mathrm{l})$ was injected into the plantar region of one hindpaw of each genotype, 30, 60, 90, 150, 240, or $360 \mathrm{~min}$ after $50 \mathrm{fmol}$ of Bv8 injected into the same paw. At each time point, a different group of five mice each from both genotypes received capsaicin injection only once. An additional mouse group from each genotype received $0.05 \mathrm{nmol}$ of capsaicin alone. After each capsaicin injection, duration of licking was recorded as described previously.

To study whether PKR1 activation potentiated capsaicin-induced thermal hyperalgesia in both genotypes, $50 \mathrm{fmol}$ of Bv8 was injected into one mouse paw $90 \mathrm{~min}$ before $0.1 \mu \mathrm{g}$ capsaicin, and the nociceptive threshold to hot water $\left(48^{\circ} \mathrm{C}\right)$ immersion was measured.

Inflammatory sensitization to mechanical and thermal stimuli was produced in the mouse hindpaws by plantar painting with mustard oil ( $10 \%$ in mineral oil; Sigma-Aldrich, Milan, Italy) or by intraplantar injection of complete Freund's adjuvant (CFA) $(20 \mu \mathrm{l}$ of a solution containing $5 \mathrm{mg}$ of CFA in $10 \mathrm{ml}$ of a 1:1 emulsion of saline and mineral oil). Before and after mustard oil application to both hindpaws, nociceptive responses to heat were measured with the hot-plate test. In CFA-induced paw inflammation, nociceptive hyperalgesia was determined with the paw immersion in hot water $\left(48^{\circ} \mathrm{C}\right)$, von Frey filaments, and weightbearing tests. The left hindpaw was inflamed with CFA injection and the right hindpaw acted as control. The differences in weight bearing, withdrawal latency to heat, and threshold force of von Frey filaments between the two hindpaws were taken as measure of the inflammatory sensitization. To evaluate paw edema elicited by CFA, paw volume of all tested mice was measured with a 7140 plethysmometer (Ugo Basile).

Body temperature. After continuously monitoring core body temperature in wild-type and pkr1-null mice for 1 week with implantable thermal probes (G2 E-Mitter probe; ER-4000 Energizer Receiver; VitalView software; Mini Mitter, Sunriver, OR), both mouse genotypes received capsaicin (1 mg/kg, s.c.), and body temperature was recorded for $3 \mathrm{~h}$.

trpv1-null mice. In C57BL/6 adult mice and in trpv1-null mice (35-40 g b.w.) (The Jackson Laboratory, Bar Harbor, ME), the nociceptive threshold to heat was measured using the hot-plate test at a temperature of $48^{\circ} \mathrm{C}$, before and after subcutaneous injection of Bv8 in dose ranging from 1 to $20 \mu \mathrm{g} / \mathrm{kg}$.

Drug injections. Topical drugs (Bv8, capsaicin, bradykinin, and PGE2) were dissolved in 10-20 $\mu \mathrm{l}$ of vehicle and injected into the plantar region of hindpaws. When required by the experimental protocol, control mice were injected with an equal volume of vehicle solution.

Laser capture microdissection. Primary sensitive neurons were microdissected from mouse DRG sections using the PALM MicroBeam system (P.A.L.M. Microlaser Technologies, Bernried, Germany) equipped with nitrogen laser $(337 \mathrm{~nm})$ for cutting, ablating, and collecting single selected neurons by the laser pressure catapulting technology. DRG frozen serial sections, cut at $10 \mu \mathrm{m}$ thickness on a cryostat, were washed in PBS solution and mounted onto a $1.35 \mu \mathrm{m}$ thin polyethylene naphthalene membrane attached to a normal slide. The size of each cell was determined using the image analysis software included in the laser capture microdissection (LCM) apparatus. Unwanted cells were individually destroyed before catapulting. After microdissection, the entire membranecell stack was ejected from the object plane, without mechanical contact, and catapulted directly into a Microfuge cap with a single laser shot for subsequent RNA extraction. We dissected 250 cells from 22-30 sections from two L4 DRGs of each mouse; three WT and three KO mice were processed.

Quantitative on-line reverse transcription-PCR. Total RNA was isolated from DRG, brain, spinal cord, and paws of wild-type and pkr1-null mice using RNeasy columns (Qiagen) or from DRG cells obtained with LCM using an ArrayPure Nano-scale RNA Purification kit (Epicentre Biotechnologies, Madison, WI) and checked for accidental degradation on Experion RNA Highsensitive Chip (Bio-Rad). RNA extracted from LCM samples was amplified using a TargetAmp 2-Round Aminoallyl-aRNA amplification kit (Epicentre Biotechnologies). Purified RNA from DRG, brain, spinal cord, and paws and LCM sample amplified RNA were used for cDNA synthesis with reverse transcriptase (Promega, Milan, Italy). An aliquot of cDNA solution was amplified using real-time PCR (iCycler; Bio-Rad), iQ SYBR Green Supermix (Bio-Rad), and $0.3 \mu \mathrm{M}$ of each primer, in a total volume of $25 \mu \mathrm{l}$. Cycling conditions were $15 \mathrm{~min}$ at $95^{\circ} \mathrm{C}$; 40 cycles of $30 \mathrm{~s}$ at $95^{\circ} \mathrm{C}, 30 \mathrm{~s}$ at $52^{\circ} \mathrm{C}$, and $30 \mathrm{~s}$ at $72^{\circ} \mathrm{C}$. Melting curve analysis of PCR products was done from 55 to $95^{\circ} \mathrm{C}$.

Specific sense and antisense primers to PCR amplify the mouse PKR1, PKR2, PK1, PK2, PK2L, and TPRV1 cDNA were synthesized (Biogen, Rome, Italy), according to the following sequences: PKR1, 5'ATTCTCGGACTTTCTTTGC-3' and 5' -GCGGCTGTTTGACACTTC3'; PKR2, 5'-ACTACCTTCGTACGGTCTCC-3' and 5'-TAACGAGGATGGTTTCTGTG-3'; PK1, 5' -AAGATCCCCTTCTTGAGGAAAC$3^{\prime}$ and $5^{\prime}$-CCAGAAAGGTTGCTTTAGGAAG-3'; PK2, 5' -CTCGGAAAGTTCCATTTTGG-3' and 5' -TTCCGGGCCAAGCAAATAAACC-3'; PK2L, 5'-CAAATGGAAGGCAGGAAAGAAG-3' and $5^{\prime}$-TTCCGGCCAAGCAAATAAACC-3'; TRPV1, 5' ${ }^{\prime}$-TGTACTTCAGCCATCGCAAG-3' and $5^{\prime}$-ACCGACACAGGTCTCTGAGG-3'; interleukin-1 $\beta$ (IL-1 $\beta$ ), $5^{\prime}$-TGAGCTGAAAGCTCTCCACC-3' and 5'-CTGATGTACCAGTTGGGGAA-3'.

To quantify the results, we constructed cDNA plasmid standards for each individual gene. cDNA standards for $\mathrm{pkr} 1, \mathrm{pkr} 2$, and trpv1 genes were generated from total RNA extracted from mouse DRG and pk1 and pk2 standards from mouse testis RNA. After reverse transcription (RT), cDNA fragments were produced by RT-PCR using the same primers as described above, purified on silica columns (QIAquick PCR purification; Qiagen) and cloned into the pGEM-T easy vector (Promega). Ligated fragments were transformed into JM109-competent cells (Promega), and plasmid DNA was purified using silica cartridges (Nucleobond AX plasmid purification; Macherey-Nagel, Duren, Germany). The exact sequence of cloned amplicons was analyzed by cycle sequencing (PRIMM, Milan, Italy). cDNA plasmid concentration was measured by $\mathrm{OD}_{260 \mathrm{~nm}}$, and the corresponding copy number was calculated using the equation 1 $\mu \mathrm{g}$ of $1000 \mathrm{bp}$ DNA $=9.1 \times 10^{11}$ molecules. Serial dilutions of the cDNA standard ranging from $10^{2}$ to $10^{7}$ input copies are used as a standard curve in each PCR run. The expression level of the gene of interest was expressed as input copy number per nanogram of input total RNA or per cell in the case of LCM samples.

In situ hybridization. RT-PCR cloning was used to obtain specific cDNA fragments for the following sequences: mouse PKR1 (GenBank accession number AF487278, nucleotides -143 to 463 ); mouse PKR2 (AF487279, nucleotides -129 to 470); mouse PK1 (AF487281, nucleotides 124-532) and mouse PK2 (AF487280, nucleotides 24-504).

The amplified cDNA fragments were subcloned into the pGEM-T easy vector (Promega), and their sequence identity was confirmed by doublestrand DNA sequencing (PRIMM). Riboprobes in antisense and sense orientation were generated from linearized vector constructs by in vitro transcription using the appropriate RNA polymerases and ${ }^{35}$ S-UTP and ${ }^{35} \mathrm{~S}$-CTP as double label. After transcription, the probes were subjected to mild alkaline hydrolysis as described previously (Angerer et al., 1987). Frozen serial sections were cut at $10 \mu \mathrm{m}$ thickness on a cryostat, thawmounted on adhesive slides, and fixed in phosphate-buffered $4 \%$ paraformaldehyde for $10 \mathrm{~min}$. Sections were washed three times in $50 \mathrm{~mm}$ PBS, pH 7.4, for 10 min each before the slides were transferred for $10 \mathrm{~min}$ to $0.4 \%$ Triton X-100. The slides were rinsed in distilled water and transferred to $0.1 \mathrm{~m}$ triethanolamine, $\mathrm{pH}$ 8.0. Acetic anhydride was added under stirring to a final concentration of $0.25 \%(\mathrm{v} / \mathrm{v})$, and sections were further incubated for $10 \mathrm{~min}$. The slides were rinsed twice in $50 \mathrm{~mm}$ PBS, $\mathrm{pH} 7.4$, for $10 \mathrm{~min}$ each before dehydration in 50 and 70\% 2-propanol. The air-dried sections were stored at $-20^{\circ} \mathrm{C}$. For hybridization, riboprobes were diluted in hybridization buffer ( $3 \times$ SSC, 50 mм NaPO4, 10 mM DTT, $1 \times$ Denhardt's solution, $20 \mathrm{mg} / \mathrm{ml}$ yeast tRNA, $10 \%$ dextran sulfate, and $50 \%$ formamide) to yield concentrations of 50,000 dpm/ $\mu$ l. After applying $50 \mu \mathrm{l}$ of hybridization solution, slides were coverslipped and incubated for $14 \mathrm{~h}$ at $60^{\circ} \mathrm{C}$. Coverslips were removed, and slides were washed in $2 \times$ SSC and $1 \times$ SSC for 20 min each, followed by incubation in RNase buffer (10 mm Tris, pH 8.0, $0.5 \mathrm{~m} \mathrm{NaCl}$, and 1 mм EDTA) containing $1 \mathrm{U} / \mathrm{ml}$ RNase $\mathrm{T} 1$ and $20 \mu \mathrm{g} / \mathrm{ml}$ RNase A (Sigma) for $30 \mathrm{~min}$ at $37^{\circ} \mathrm{C}$. The slides were washed at room temperature in $1 \times$ and $0.2 \times$ 
SSC for $20 \mathrm{~min}$ each, at $60^{\circ} \mathrm{C}$ in $0.2 \times$ SSC for $60 \mathrm{~min}$, and at room temperature in $0.2 \times$ SSC for $10 \mathrm{~min}$. The tissue was dehydrated in 50 and $70 \%$ 2-propanol and air dried. Slides were exposed to x-ray film for $5 \mathrm{~d}$. For emulsion autoradiography, slides were dipped into NTB Kodak autoradiography emulsion (Integra Biosciences, Fernwald, Germany) and exposed for 3 weeks. The specificity of the hybridization signal for each probe was ascertained by hybridization of adjacent sections with labeled sense probe and labeled antisense probe with a 1000 -fold excess of cold antisense probe. Neurons were stained with $0.1 \%$-toluidine blue solution.

Calcium imaging and DRG cultures. DRG neuronal cultures from adult pkr1-null and WT mice were obtained as described previously (Vellani et al., 2001). In brief, isolated ganglia were digested in collagenase (type IV; Worthington Biochemical, Lakewood, NJ), mechanically dissociated, plated on glass coverslips coated with poly-L-lysine and laminin (Sigma), and maintained in a DMEM (Invitrogen, Carlsbad, CA) containing 100 $\mathrm{ng} / \mathrm{ml}$ nerve growth factor, $10 \%$ fetal bovine serum, penicillin, and streptomycin. Calcium measurements were performed after 2-3 d in culture using Fluo-4 AM (Invitrogen, Eugene, OR) as calcium dye. Cells were loaded for $15 \mathrm{~min}$ with a serum-free medium containing $10 \mu \mathrm{M}$ Fluo-4 $\mathrm{AM}$ and then washed in the following Krebs'-Ringer's solution buffered with HEPES (KRH) (in mM): $125 \mathrm{NaCl}, 5 \mathrm{KCl}, 2 \mathrm{CaCl}_{2}, 1.2 \mathrm{KH}_{2} \mathrm{PO}_{4}, 1.2$ $\mathrm{MgSO}_{4}, 25$ HEPES, $\mathrm{pH}$ 7.4. Coverslips were mounted onto Leica (Wetzlar, Germany) SP2 confocal microscope, connected with a doublewavelength CAM-230 microfluorimeter (Jasco, Easton, MD). The fluorescent images were recorded by an intensified CCD camera (Photonic Science, Robertsbridge, UK), transferred to a digital processor, digitalized and integrated, and the fluorescence intensity was measured. Neurons were distinguished from non-neuronal cells at the start of the experiment by applying $25 \mathrm{~mm} \mathrm{KCl}$, which induce a rapid increase of $\left[\mathrm{Ca}^{2+}\right]_{\mathrm{i}}$ in neurons. To identify neurons responding to both Bv8 and capsaicin, Bv8 was added to DRG cultures at $50 \mathrm{~nm}$ concentration, $10 \mathrm{~min}$ before $1 \mathrm{~mm}$ capsaicin, and $\left[\mathrm{Ca}^{2+}\right]_{\mathrm{i}}$ fluorescence was recorded for $180 \mathrm{~s}$ after the addition of each agonist.

Morphology of DRG neurons. L4 and L5 DRG were removed from wild-type and pkr1-null mice ( $n=4$ animals per genotype), fixed for 90 min in $4 \%$ paraformaldehyde solution at $4^{\circ} \mathrm{C}$, washed in PBS, and soaked overnight in $20 \%$ sucrose at $4^{\circ} \mathrm{C}$. Each DRG was embedded in Neg-50 (Richard Allen Scientific, Kalamazoo, MI), frozen, and cut in a cryostat at $10 \mu \mathrm{m}$ thickness. Sections ( $n=12-17$ from each DRG) were stained with $0.1 \% o$-toluidine blue solution at $\mathrm{pH} 4.5$, and non-neuronal cells were detected by glial fibrillary acidic protein immunostaining of adjacent sections (polyclonal rabbit GFAP antibody, 1:500 final concentration; Dako, Milan, Italy). Total numbers of neurons showing a distinct nucleus were counted in each section, and cell area was determined for each neuron using a computer image analysis software (MCID Elite; Imaging Research, St. Catharines, Ontario, Canada). Distribution histograms were generated for each genotype and analyzed using Prism 4 computer software (GraphPad, San Diego, CA).

Statistics. The data are presented as mean \pm SE mean values. Statistical analyses were performed using one-way ANOVA or two-way ANOVA with genotype and time as independent variables. Follow-up analysis was performed using the Bonferroni test. Total cell count and distribution of cell size were compared between the two genotypes using ANOVA comparison of log-transformed distribution data.

\section{Results}

\section{Morphology of DRG neurons}

Toluidine blue staining of neuron profiles and immunostaining for GFAP of non-neuronal cells showed no changes in morphology of DRG from pkr1-null mice compared with WT mice (Fig. 1 ). The analysis of size distribution of DRG neurons disclosed no significant difference between WT and pkr1-null mice (Fig. 1E)

\section{PKRs in mouse DRG}

Quantitative RT-PCR analysis of DRG-extracted RNA (Fig. 2 B) detected PKR1, PKR2, and TPRV1 transcripts in wild-type mice. PKR1 expression was $\sim 8$ times higher than PKR2 but 2.5 times
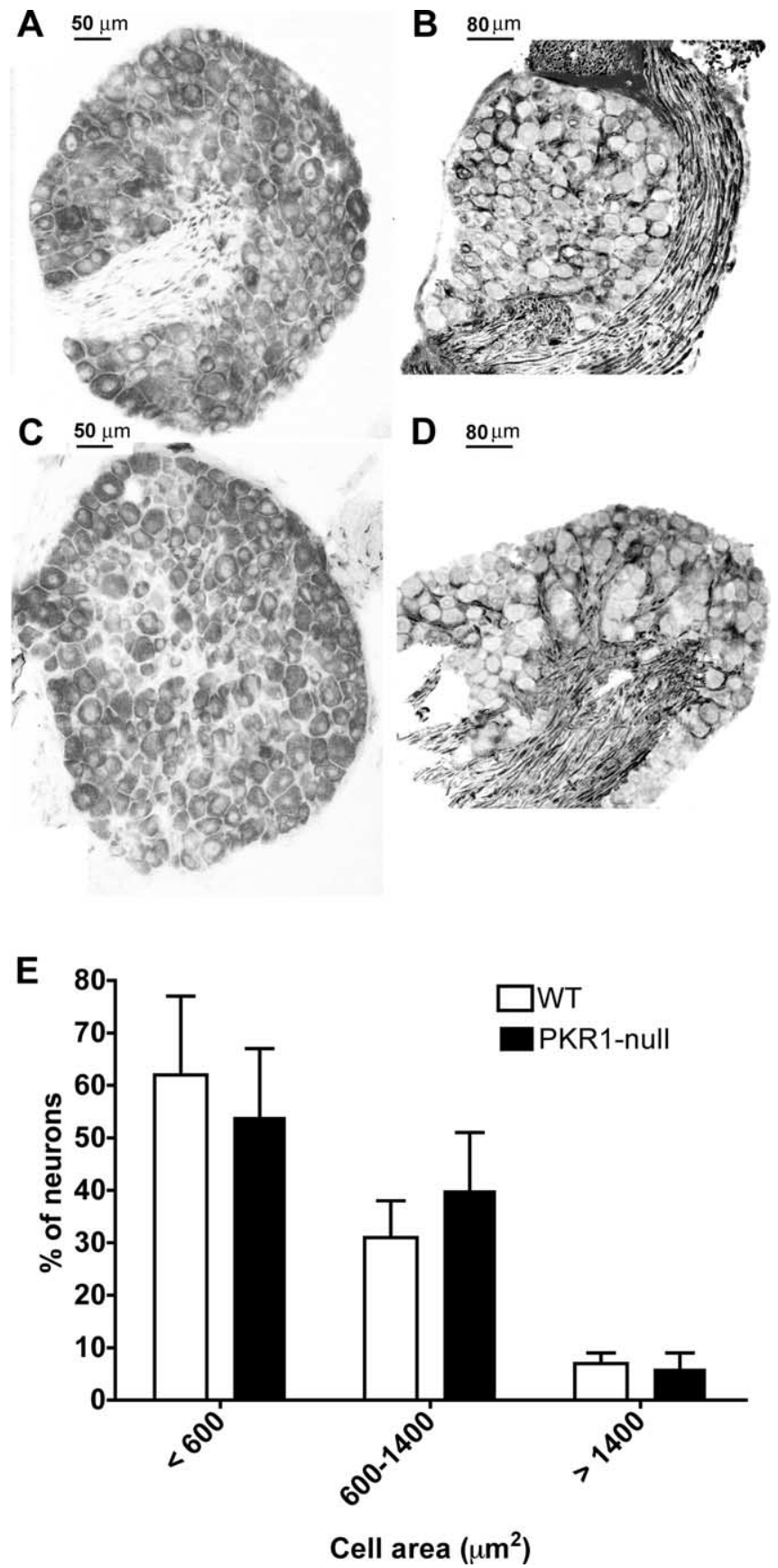

Figure 1. Morphology of DRG neurons in $\mathrm{pkr} 1^{+/+}$and $\mathrm{pkr} 1^{-/-}$mice. $A-D$, Microphotographs of DRG sections from wild-type $(\boldsymbol{A}, \boldsymbol{B})$ and PKR1-null $(\boldsymbol{C}, \boldsymbol{D})$ mice, stained with o-toluidine blue $(\boldsymbol{A}, \boldsymbol{C})$ and immunostained with GFAP antibody $(\boldsymbol{B}, \boldsymbol{D})$. $\boldsymbol{E}$, Size distribution of DRG neurons in WT and PKR1-null mice. Cell body area did not show significant difference between the two genotypes. For each size category, only neurons with visible nucleus were counted.

lower than TPRV1 expression. DRG from pkr1-null mutant mice completely lacked PKR1 transcript but expressed both PKR2 and TRPV1 transcripts normally (Fig. 2B). No differences were found in PKR2 and TRPV1 transcript levels in the brain and spinal cord of the two genotypes (data not shown).

To identify whether PKR1 and PKR2 are coexpressed in DRG neurons and colocalize with TRPV1, we performed RT-PCR analysis of the three gene expressions on each single neuron of 250 laser-microdissected cells from both L4 DRG of each mouse, using three mice for each genotype. RT-PCR analysis showed that PKR1 and PKR2 were not coexpressed. We detected PKR1 in 


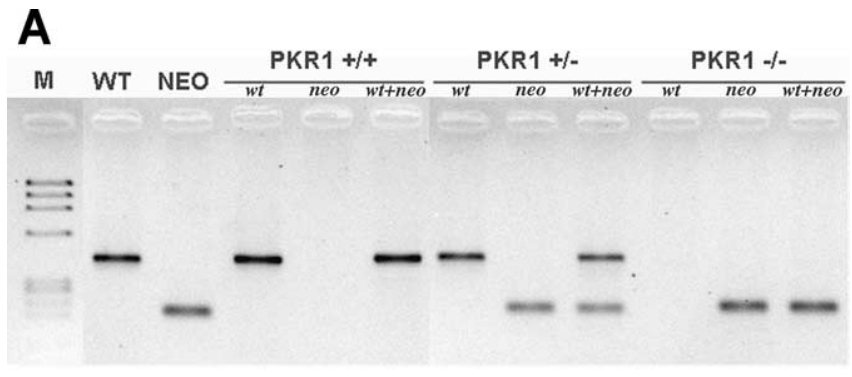

B

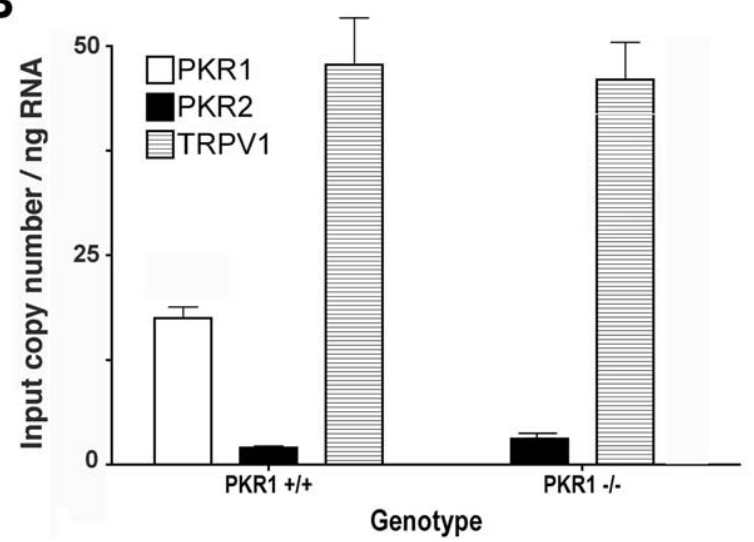

Figure 2. Mouse tail DNA genotyping and DRG mRNA expression of PKR genes. $A$, Representative example of wild-type $\left(\right.$ PKR1 ${ }^{+/+}$), heterozygous mutant (PKR1 ${ }^{+/-}$), and homozygous mutant $\left(\right.$ PKR1 ${ }^{-I-}$ ) mouse tail DNA genotyped by PCR. Lane WT contains PCR amplification product of wild-type PKR1 gene; lane NEO contains PCR amplification product of the mutant gene; lanes wt contain PCR amplification products obtained with primers for wild-type PKR1 gene; lanes neo contain PCR amplification products obtained with primers for the mutant gene; lanes $w t+$ neo indicate multiplex PCR for both WT and mutant gene; lane M contains DNA molecular weight markers. $\boldsymbol{B}$, Expression of the genes PKR1, PKR2, and TRPV1 in DRG from wild-type $\left(\right.$ PKR1 ${ }^{+/+}$) and PKR1-null mutant (PKR1 ${ }^{-/-}$) mice.

$28.4 \pm 3.1 \%$, PKR 2 in $13.8 \pm 1.2 \%$, and TRPV 1 in $38.7 \pm 3.1 \%$ of laser-microdissected DRG cells from WT mice. Dissected cells were divided into three categories according to cell area (Shi et al., 2006): small neurons (area $<600 \mu \mathrm{m}^{2}$ ), medium-sized neurons (area $>600$ and $<1400 \mu \mathrm{m}^{2}$ ), and large neurons (area $>1400$ $\mu \mathrm{m}^{2}$ ). Small neurons represent $84.5 \pm 4.9 \%$, medium-sized neurons $14.3 \pm 0.8 \%$, and large neurons $1.2 \pm 0.7 \%$ of the PKR 1 expressing neuronal population. PKR2 was prevalently expressed by medium-sized neurons, and TRPV1 was expressed in small neurons (Fig. 3A). No differences were found in the expression of PKR2 and TRPV1 between the two genotypes. In WT mice (Fig. $3 B)$, we found a significant population $(68.5 \pm 6.6 \%)$ of TRPV1expressing neurons that also showed PKR1 transcripts, whereas only $9.4 \pm 1.3 \%$ of TRPV1-expressing neurons coexpressed PKR2. In pkr1-null mutant mice (Fig. $3 B$ ) $16.4 \pm 1.1 \%$ of TRPV1-expressing neurons also expressed PKR2, but no neuron expressed PKR1. Agarose gel electrophoresis of PCR amplification products showed that in small neurons coexpressing TRPV1 with PKR1, the TRPV1 band was approximately three to four times more intense than the PKR1 band. A similar density ratio between TRPV1 and PKR2 bands was also found in small neurons coexpressing the two receptors. In contrast, in mediumsized neurons coexpressing TRPV1 with PKR1 or with PKR2, the bands of the corresponding PCR amplification products were of comparable intensity (Fig. 3C).

In situ hybridization with riboprobes directed against PKRs confirmed that in DRG from wild-type mice, PKR1 was preva-

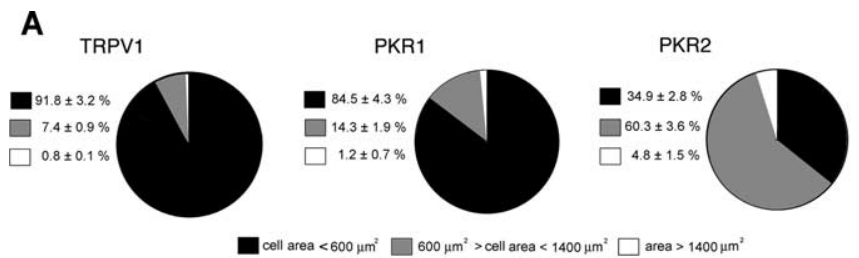

B
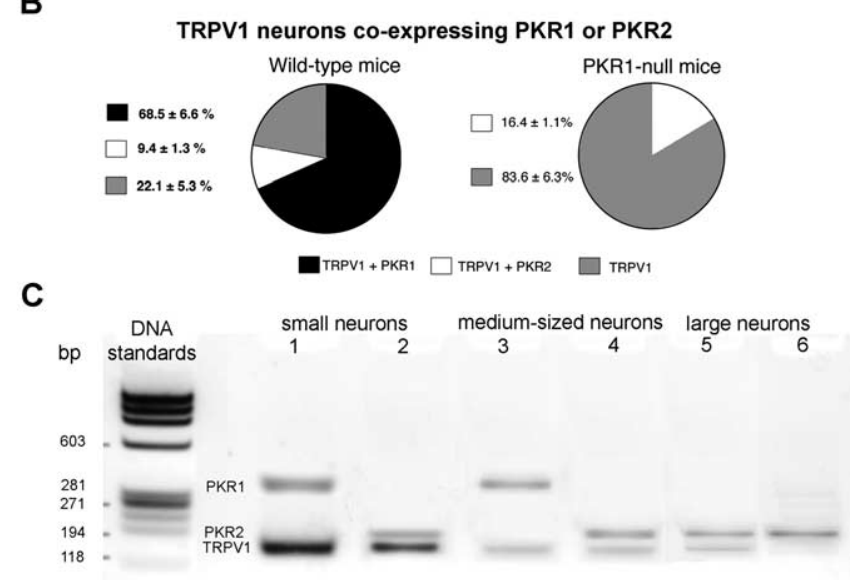

Figure 3. On-line RT-PCR of PKR1, PKR2, and TRPV1 mRNAs from laser-microdissected DRG neurons and gel electrophoresis of $P C R$ amplification products of the three genes. $A$, Size distribution of neurons from wild-type and PKR1-null mice, expressing TRPV1, PKR1, and PKR2. B, Percentage of TRPV1 neurons coexpressing PKR1 or PKR2. C, Gel electrophoresis of PCR amplification products from representative samples of small, medium-sized, and large DRG neurons.
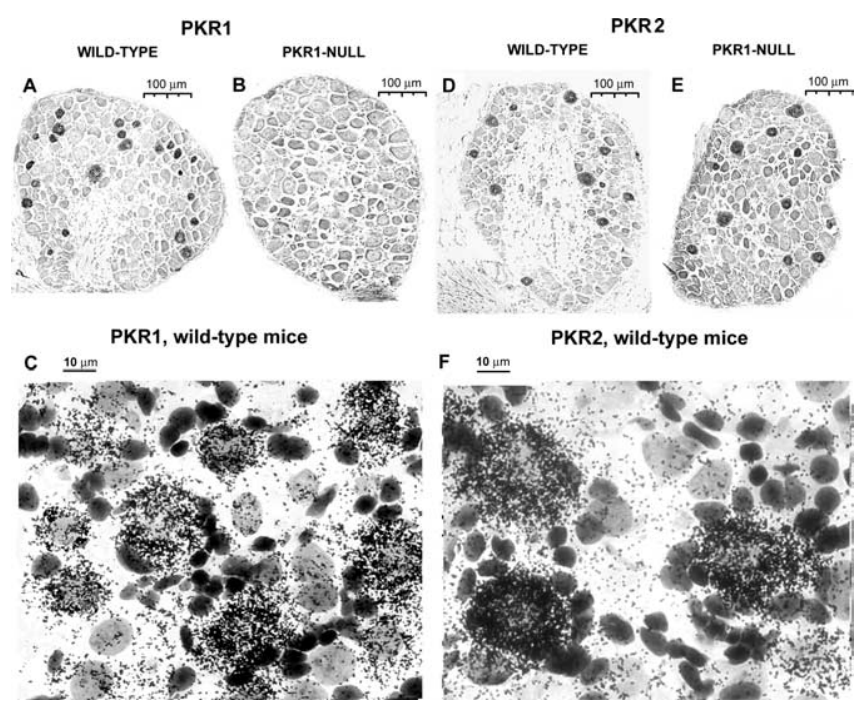

Figure 4. In situ hybridization of DRG sections with ${ }^{35} \mathrm{~S}$-PKR1 and ${ }^{35}$ S-PKR2 antisense riboprobe. $\boldsymbol{A}, \boldsymbol{C}, \boldsymbol{D}, \boldsymbol{F}$, Wild-type mice; $\boldsymbol{B}, \boldsymbol{E}$, PKR1-null mice. PKR1 is expressed by neurons smaller than those expressing PKR2. $\boldsymbol{A}, \boldsymbol{B}, \boldsymbol{D}, \boldsymbol{E}$, Cell profiles stained with $\boldsymbol{0}$-toluidine blue; $\boldsymbol{C}, \boldsymbol{F}$, Nuclei stained with Mayer's hemalum.

lently expressed by small cells and PKR2 by medium-sized cells (Fig. 4). Small-sized cells labeled by PKR1 riboprobe were approximately four times more abundant than those expressing PKR2. A high density of PKR1 and PKR2 mRNA was also present in the trigeminal ganglion neurons of wild-type mice. DRG neurons from null mutant mice expressed no PKR1 transcript, but expressed PKR2 normally. PK1 and PK2 transcripts were absent in DRG neurons from both genotypes. 

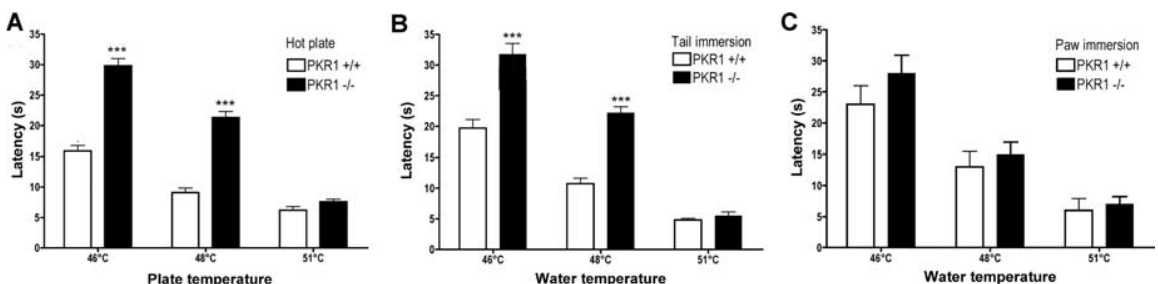

Figure 5. Impaired thermal nociception in PKR1-null mutant mice. $\boldsymbol{A}$, Paw-withdrawal latency from hot plate. $\boldsymbol{B}$, Tailwithdrawal latency from hot water were significantly longer in PKR1-null mutant mice than wild-type mice at stimulant temperature lower than $50^{\circ} \mathrm{C}$. C, Hot water at mouse paw did not reveal any difference in withdrawal latency between the two genotypes. ${ }^{* * *} p<0.001$ versus wild-type mice (2-way ANOVA with Bonferroni's post test).

\section{Calcium responses in cultured DRG neurons}

The percentage of neurons that showed intracellular calcium responses to $50 \mathrm{~nm} \mathrm{Bv8}$ was $8.3 \pm 0.7 \%$ in cultured DRG from WT mice but only $1.5 \pm 0.5 \%$ in DRG from pkr1-null mutant mice $(p<0.001)$. This percentage is significantly lower than that of PKR-expressing neurons from laser-microdissected DRG and probably indicates that cultured PKR-expressing neurons had inserted only a fraction of the translated prokineticin receptor proteins in their plasma membrane. When $1 \mu \mathrm{M}$ capsaicin was added to DRG cultured neurons previously tested with Bv8, the percentage of Bv8-responding neurons that also showed intracellular calcium responses to capsaicin was $78 \pm 1.7 \%$ in cultures from WT mice but only $27 \pm 0.9 \%$ in those from pkr1-null mutant mice $(p<0.001)$.

\section{Nociception in pkr1-null mutant mice}

pkr1-null mutant mice showed impaired responses to noxious heat. In the hot-plate test at temperatures lower than $50^{\circ} \mathrm{C}$, the baseline latency for response was significantly longer (1.5- to 2.3-fold) compared with the latencies seen in wild-type mice (Fig. $5 A)$. At $51^{\circ} \mathrm{C}$ the latency to response was comparable in the two genotypes. When hot water was used as the noxious stimulus applied to the mouse tail, a similar hypoalgesia was observed in the pkr1-null mutant mice. At water temperatures ranging from 43 to $48^{\circ} \mathrm{C}$, withdrawal latencies were $\sim 1.5-2$ times longer in PKR1-deficient mice than in wild-type mice (Fig. 5B). Radiant heat applied to the plantar region of hindpaws (Hargreaves' test) and the tail tip (data not shown) and hot $\left(48^{\circ} \mathrm{C}\right)$ water to the mouse paw disclosed no difference in withdrawal latency between the two genotypes (Fig. $5 C$ ). In addition, tactile threshold determined by von Frey filaments did not differ between the two genotypes (see Fig. $7 C$, baseline values at $0 \mathrm{~min}$ ).

When we assessed nocifensive behavior by injecting dilute acetic acid into the peritoneum of the two mouse genotypes, the acid induced significantly less intense and shorter-lasting writhing episodes in pkr1-null mice than in wild-type mice (Fig. 6A).

In wild-type mice, capsaicin injected into the plantar skin of the hindpaw at doses ranging from 0.05 to $5 \mathrm{nmol}$ elicited a robust licking and shaking of the paw, but in pkr1-null mice all capsaicin doses tested induced a significantly reduced response (Fig. 6B). Intrapaw injection of bradykinin (5-50 $\mu \mathrm{g})$ induced comparable licking in the two genotypes (data not shown).

When we evaluated whether, and to what extent, PKR1 contributed to trigeminal nociception by adding to sweetened drinking water capsaicin at concentrations ranging from 10 to $100 \mu \mathrm{M}$, even at the lowest capsaicin concentration wild-type mice promptly reduced the volume they drank and at capsaicin concentration higher than $30 \mu \mathrm{M}$ took one sip of the solution, rubbed their snouts vigorously, and avoided additional consumption. pkr1-null mutant mice drank significantly larger volumes of capsaicin-containing water than wild-type mice. Only at capsaicin concentrations $\geq 30 \mu \mathrm{M}$ did the pkr1null mice drink a significantly lower volume of capsaicin-containing water than sweetened water (Fig. 6C).

\section{Nociceptive sensitization by proalgesic agents}

Nociceptive sensitization was induced by proalgesic agents, Bv8, capsaicin, bradykinin, and PGE2 and studied in both mouse genotypes. As reported previously in rats (Negri et al., 2002), Bv8 also produced a potent nociceptor sensitization in mice. Subcutaneous (from 1 to $10 \mu \mathrm{g} / \mathrm{kg}$ ) (Fig. $7 A$ ) and intraplantar (from 0.1 to $0.5 \mathrm{ng}$ ) (Fig. $7 B$ ) injections of Bv8 in wild-type mice produced intense and long-lasting sensitization to thermal stimuli (hot plate). In contrast, when injected in PKR1deficient mice, these subcutaneous and plantar doses of Bv8 left the nociceptive threshold unchanged. Bv8 doses 30-100 times higher than the doses tested in wild-type mice were, however, capable of eliciting hyperalgesia in PKR1-deficient mice.

In wild-type mice, intraplantar injection of $0.5 \mathrm{ng}$ of Bv8 evoked tactile allodynia, which lasted as long as heat hyperalgesia. This intraplantar dose of Bv8 also produced comparable tactile allodynia in pkr1-null mice (Fig. 7C)

After intraplantar injection of $0.5 \mathrm{ng}$ of Bv8, the left hindpaw of wild-type mice bore a significant lower fraction of body weight than saline-injected contralateral paw. When injected into the left hindpaw of pkr1-null mice, this dose of Bv8 left the weight borne by the paw unchanged (Fig. 7D).

In wild-type mice, activation of TRPV1 by intrapaw injection of $12 \mu \mathrm{g}$ of capsaicin produced an intense and long-lasting sensitization to thermal stimuli $\left(48^{\circ} \mathrm{C}\right.$, paw immersion into hot water). In pkr1-null mice, intrapaw injection of capsaicin did not induce thermal hyperalgesia (Fig. $8 \mathrm{~A}$ ). In contrast, bradykinin $(2$ $\mu \mathrm{g}$ ) or PGE2 (from 0.1 to $1 \mu \mathrm{g}$ ) injected into the mouse paw elicited comparable thermal hyperalgesia in both mouse genotypes (data not shown).

In WT mice, an intraplantar capsaicin dose of $0.05 \mathrm{nmol}$ induced licking for $8 \pm 2.7 \mathrm{~s}$. When a dose of capsaicin five times lower $(0.01 \mathrm{nmol})$ was injected in the same paw in which $50 \mathrm{fmol}$ Bv8 was previously injected from 30 to $360 \mathrm{~min}$, a robust licking and shaking of the paw was elicited. Licking reached a maximum of $108.6 \pm 7.6 \mathrm{~s}$ when capsaicin was injected 90 min after Bv8; the sensitizing effect disappeared within $6 \mathrm{~h}$ after Bv8 injection. In pkr1-null mice, $0.05 \mathrm{nmol}$ of capsaicin injected alone or 0.01 nmol of capsaicin injected from 30 to $360 \mathrm{~min}$ after $50 \mathrm{fmol}$ of Bv8 did not induce licking (Fig. $8 \mathrm{~B}$ ).

In WT mice, intraplantar $0.1 \mu \mathrm{g}$ of capsaicin induced a weak thermal hyperalgesia. When this dose of capsaicin was injected 90 min after $50 \mathrm{fmol}$ of Bv8 into the same paw, an intense hyperalgesia to hot water $\left(48^{\circ} \mathrm{C}\right)$ was elicited. In pkr1-null mice, Bv8 did not pontentiate the capsaicin-induced thermal hyperalgesia (Fig. 8C).

\section{Body temperature}

In wild-type mice, subcutaneous injection of capsaicin $(1 \mathrm{mg} / \mathrm{kg})$ produced a profound $\left(-6 \pm 0.5^{\circ} \mathrm{C}\right)$ reduction of body temperature that reached its nadir by $30 \mathrm{~min}$ and recovered within $3 \mathrm{~h}$. The same dose of capsaicin lowered body temperature of pkr1null mice $<1^{\circ} \mathrm{C}$ (Fig. 9). 

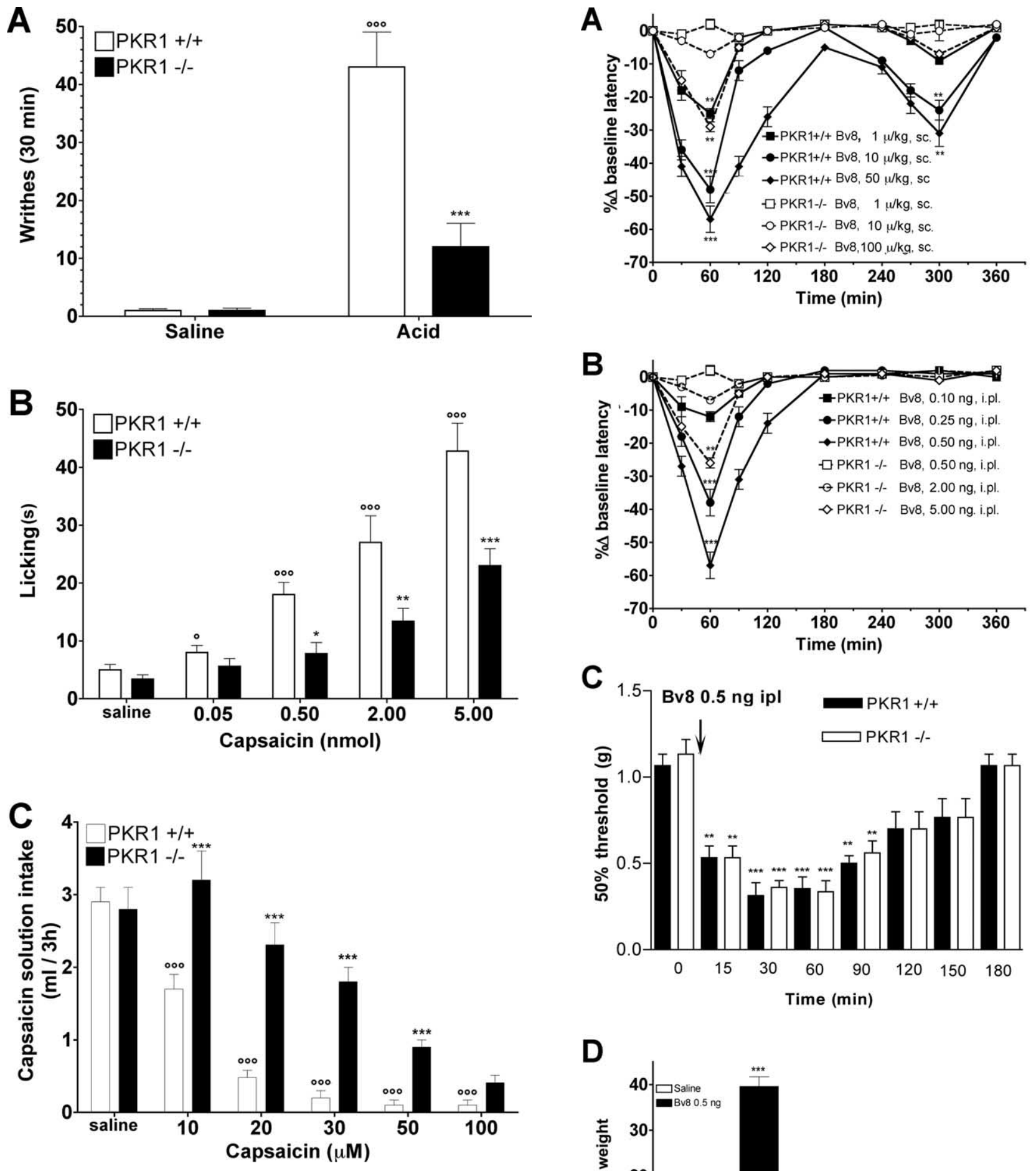

Figure 6. Impaired chemical nociception in pkr1-null mutant mice. $\boldsymbol{A}$, pkr1-null mice showed a reduced number of writhes in response to intraperitoneal acetic acid compared with wild-type mice. ${ }^{000} p<0.001$ versus saline; ${ }^{* * *} p<0.001$ versus wild-type mice. $B$, Dosedependent paw licking time after intraplantar capsaicin was shorter in pkr1-null mice than in wild-type mice. ${ }^{\circ} p<0.05,{ }^{\circ 0} p<0.01,{ }^{000} p<0.001$ versus vehicle; ${ }^{*} p<0.05$, ${ }^{* *} p<0.01$, ${ }^{* * *} p<0.001$ versus wild-type mice. $C$, pkr1-null mutant mice drank a larger volume of capsaicin solution than wild-type mice showing impaired trigeminal nociception. ${ }^{\circ 00} p<0.001$ versus vehicle, ${ }^{* * *} p<0.001$ versus wild-type mice (2-way ANOVA with Bonferroni's post test).

Bv8-induced hyperalgesia in trpv1-null mice

In wild-type mice, subcutaneous injection of $1 \mu \mathrm{g} / \mathrm{kg} \mathrm{Bv} 8 \mathrm{de}-$ creased by $\sim 50 \%$ the nociceptive threshold to thermal stimuli, whereas a dose at least 20 times higher $(20 \mu \mathrm{g} / \mathrm{kg})$ was necessary to produce comparable hyperalgesia in trpv1-null mice (Fig. 10).

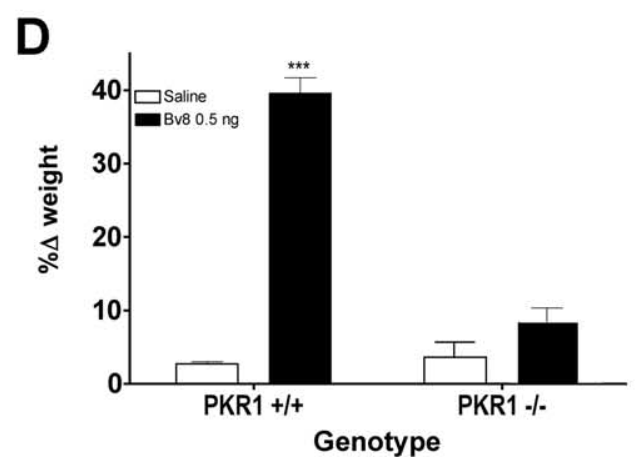

Figure7. Bv8-induced hyperalgesia to heat (hot platetest), punctatestimuli (von Frey filaments), and body weight bearing (weight bearing averager) in wild-type (PKR1 ${ }^{+/+}$) and pkr1-null $\left(\right.$ PKR1 $\left.{ }^{-1-}\right)$ mice. $A$, Time course of thermal hyperalgesia elicited by subcutaneous doses of Bv8. $\boldsymbol{B}$, Time course of thermal hyperalgesia elicited by intraplantar (i.pl.) doses of Bv8. C, Time course of tactile hyperalgesia measured with von Frey filaments in mice intraplantarly injected with Bv8. D, Percentage difference of body weight borne by Bv8-injected paws in wild-type mice $\left(\right.$ PKR $\left.^{+/+}\right)$and PKR1-null mutant mice (PKR1 ${ }^{-l-}$ ). ${ }^{* *} p<0.01,{ }^{* * *} p<0.001$ versus saline (2-way ANOVA with Bonferroni's post test). 

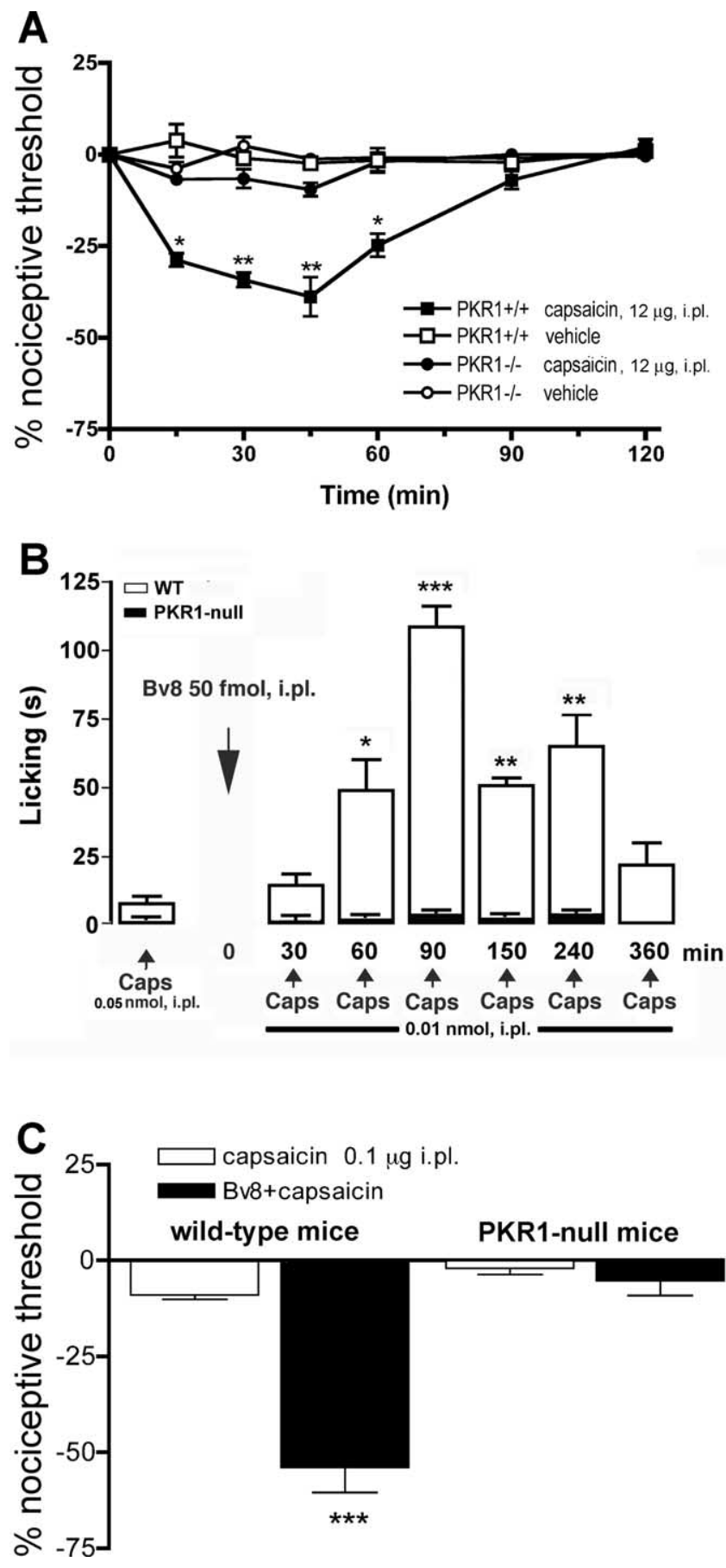

Figure 8. Capsaicin induced thermal hyperalgesia and Bv8 sensitized to capsaicin-induced licking and thermal hyperalgesia in WT mice and PKR1-null mice. A, Intraplantar (i.pl.) injection of $12 \mu \mathrm{g}$ capsaicin produced an intense and long-lasting sensitization to thermal stimuli (paw immersion into $48^{\circ} \mathrm{C}$ water) in wild-type mice but not in PKR1-null mice. $\boldsymbol{B}$, Intraplantar capsaicin (Caps) at dose level of $0.05 \mathrm{nmol}$ induced licking in wild-type mice but not in PKR1-null mice. In contrast, a five times lower dose of capsaicin injected from 60 to $240 \mathrm{~min}$ after $50 \mathrm{fmol}$ of Bv8 elicited a robust licking in WT mice but not in mutant mice. C, Bv8 (50 fmol) injected intraplantarly 90 min before $0.1 \mu \mathrm{g}$ capsaicin strongly potentiated thermal hyperalgesia in wild-type mice but not in PKR1-null mice. ${ }^{*} p<0.05,{ }^{* *} p<0.01$, and ${ }^{* * *} p<0.001$ versus baseline values (2-way ANOVA with Bonferroni's post test).

Inflammatory hyperalgesia

Painting both hindpaws with mustard oil solution produced comparable light paw edema in wild-type and pkr1-null mice, suggesting similar acute neurogenic inflammatory responses. In

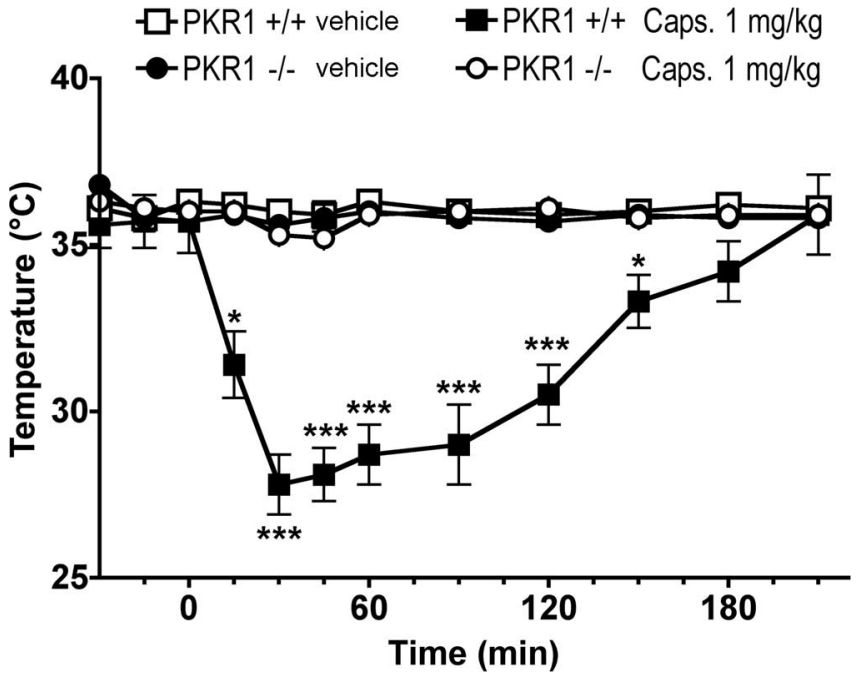

Figure 9. Impaired capsaicin (Caps.)-induced hypothermia in pkr1-null mutant mice. Hypothermic response to subcutaneous capsaicin $(1 \mathrm{mg} / \mathrm{kg})$ in wild-type mice (PKR1 $\left.{ }^{+/+}\right)$and in pkr1-null mutant mice $\left(\right.$ PKR1 $\left.{ }^{-1-}\right) .{ }^{*} p<0.05$ and ${ }^{* * *} p<0.001$ versus pkr1-null mice (2-way ANOVA with Bonferroni's post test).

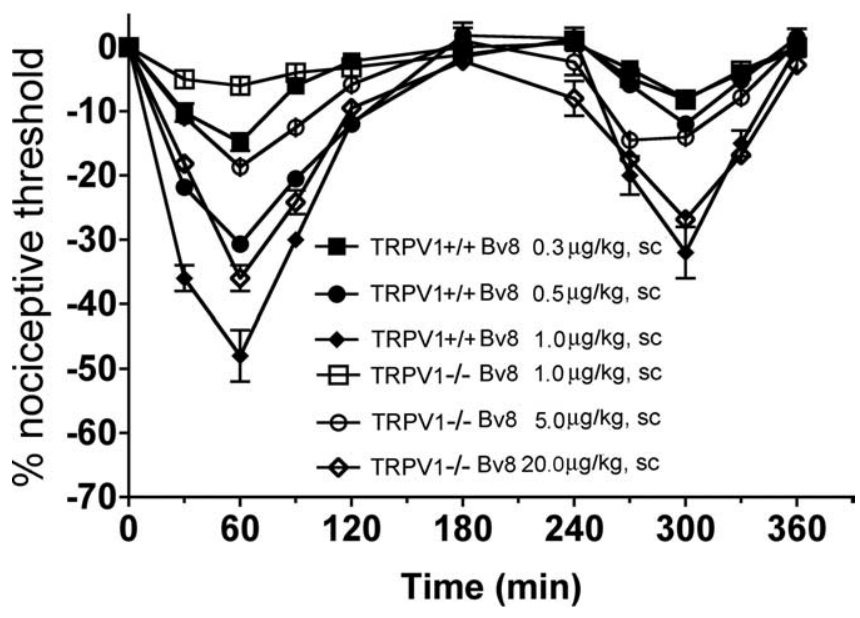

Figure 10. Deletion of the vanilloid receptor TRPV1 gene reduced the nociceptive response to PKR activation by Bv8. The decrease in nociceptive threshold to heat produced by a subcutaneous injection of $20 \mu \mathrm{g} / \mathrm{kg}$ Bv8 in trpv1-null mice (TRPVR1 ${ }^{-1-}$ ) was comparable to that obtained in wild-type mice (TRPV1 ${ }^{+/+}$) by a Bv8 dose of $1 \mu \mathrm{g} / \mathrm{kg}$.

wild-type mice, tested with the hot plate at $48^{\circ} \mathrm{C}$, thermal hyperalgesia developed within 15 min after application of mustard oil and reached $35 \pm 3 \%$ of the baseline paw-withdrawal latency at $30 \mathrm{~min}$, lasting 80-90 min. In contrast, in pkr1-null mice, the thermal nociceptive threshold decreased slightly $(-18 \pm 2 \%)$ and recovered within $60 \mathrm{~min}$ (Fig. 11A).

Because the baseline paw-withdrawal threshold elicited by the hot water $\left(48^{\circ} \mathrm{C}\right)$ immersion test did not differ in the two genotypes, we used this test to compare CFA-induced inflammatory sensitization in WT and KO mice. Disruption of the pkrl gene significantly reduced thermal nociceptive hypersensitivity at 6 , 24 , and $36 \mathrm{~h}$ after CFA intraplantar injection (Fig. $11 \mathrm{~B}$ ). No difference in the paw edema was evident between the two genotypes. The mean increase in paw volume $24 \mathrm{~h}$ after CFA injection was $80 \pm 6 \mu \mathrm{l}$ in WT mice and $73 \pm 3 \mu \mathrm{l}$ in pkr1-null mice.

Relative weight distribution between inflamed and noninflamed hindpaw (incapacitance test) revealed that $24 \mathrm{~h}$ after CFA injection, WT mice developed a significant reduction in weight 


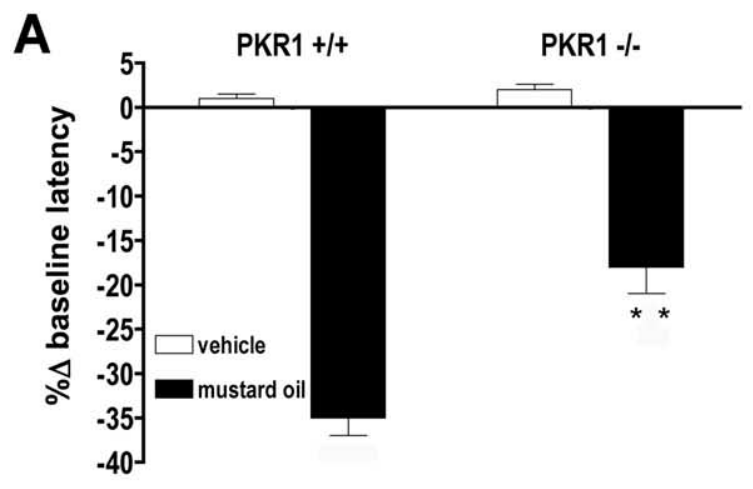

B
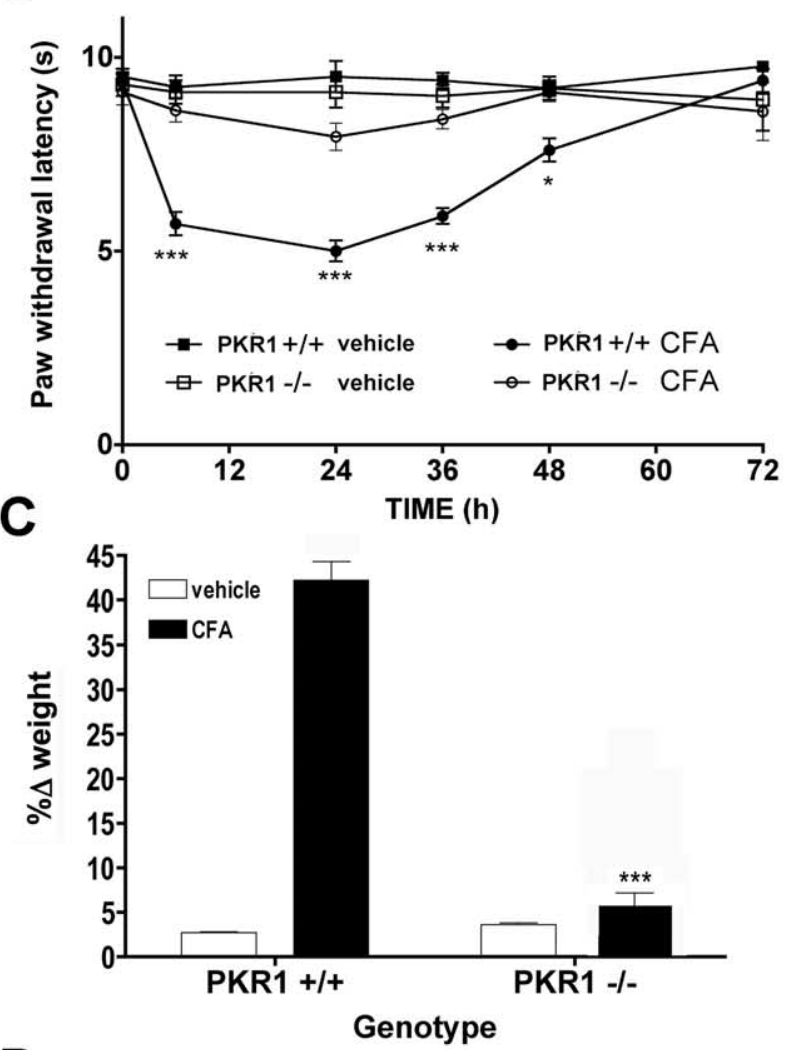

D

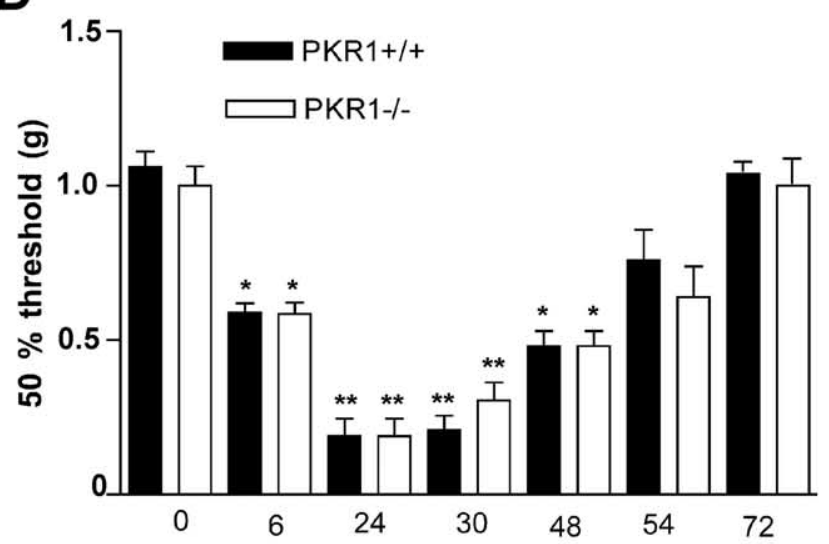

Time after CFA injection (h)

Figure 11. Inflammatory hyperalgesia in pkr1-null mutant mice. $\boldsymbol{A}$, Acute inflammatory hyperalgesia induced by painting both hindpaws with mustard oil was less intense in pkr1-null mice compared with wild-type mice (hot plate test). $\boldsymbol{B}, \boldsymbol{C}$, Chronic inflammatory hyperalgesia elicited by intrapaw injection of CFA was impaired in mutant (PKR1 $\left.{ }^{-1-}\right)$ mice $(\boldsymbol{B}$, paw immersion in bearing on the inflamed paw, whereas pkr1-null mice showed no difference in weight bearing between the two hind paws (Fig. 11C).

Comparable tactile allodynia (von Frey filaments) was recorded in inflamed paws of both mouse genotypes $24 \mathrm{~h}$ after CFA injection (Fig. 11D).

\section{PK2, PK2L, PKR1, and IL-1 $\beta$ expression in inflamed paws}

RT-PCR revealed that PK2, PK2L, and PKR1 expression in inflamed skin of WT mice paws $24 \mathrm{~h}$ after CFA injection were from 15 to 29 times higher than that in contralateral saline-injected paw (Table 1). Deletion of pkr1 gene significantly reduced the PK2 and PK2L inflammatory increase. There was no significant difference between the two genotypes in the inflammatory increase of IL- $1 \beta$. Preliminary data of in situ hybridization with a digoxigenin-labeled $\mathrm{PK} 2$ riboprobe showed a strong reduction in the number of PK2-expressing inflammatory cells in pkr1-null mouse inflamed skin (E. Giannini, personal communication).

\section{Discussion}

Deletion of the mouse pkr1 gene produced the following nociceptive deficits: (1) impaired activation of nociceptors by noxious heat and protons, stimuli known to act through the TRPV1 cation channel, leaving tactile threshold unchanged; (2) impaired nociceptor sensitization to heat and capsaicin produced by the PKR1 agonist Bv8, leaving Bv8-induced tactile allodynia to develop normally; (3) impaired nociceptor activation and sensitization to heat by mustard oil and capsaicin; and (4) impaired expression of inflammatory thermal hyperalgesia and reduced inflammatory pain sensation. Collectively, these findings demonstrate a role of the PKR1 receptor in modulating nociceptor threshold to heat, protons, and noxious chemicals and suggest that blockade of PKR1 may be a novel strategy that can diminish the activation and sensitization of primary afferent nociceptors to produce therapeutic benefit in acute and inflammatory pain conditions.

The present study also emphasizes a positive interaction between the PKR1 G-protein-coupled receptor and the nonselective cation channel TRPV1. A significant proportion of small neurons $\left(<600 \mu \mathrm{m}^{2}\right.$ area $)$ coexpressed PKR1 with TRPV1 in DRG from wild-type mice, providing an anatomical basis for PKR1/TRPV1 interactions. Accordingly, in DRG cultures from pkr1-null mice, Bv8-responsive neurons showed a reduced $\left[\mathrm{Ca}^{2+}\right]_{\mathrm{i}}$ response to capsaicin. Compared with WT mice, pkr1-null mice showed a strong reduction of nociceptive and thermal effects resulting from capsaicin-induced activation of the vanilloid receptor. Moreover, the trpv1 gene deletion strongly reduced the hyperalgesia to noxious thermal stimuli evoked by the PKR agonist Bv8, suggesting that TRPV1 is implicated in the Bv8-induced heat hyperalgesia. All of these findings agree on a positive interaction between PKR1 and TRPV1 throughout the peripheral nervous system, including the trigeminal system. The modulatory role of PKR1 in TRPV1 activation is also suggested by heat hypoalgesia and diminished writhing responses to intraperitoneal acetic acid in pkr1-null mice. The TRPV1 channel is known to be a critical molecular transducer of heat and is modulated by protons. Nociceptive deficits in pkr1-null mice were

$\leftarrow$

hot water; $\boldsymbol{C}$, body weight bearing test). ${ }^{* *} p<0.01$ and ${ }^{* * *} p<0.001$ versus wild-type mice (2-way ANOVA with Bonferroni's post test). $\boldsymbol{D}$, In contrast, comparable tactile allodynia (von Frey filaments) was recorded in inflamed paws of both mouse genotypes after (FA injection. ${ }^{*} p<0.05,{ }^{* *} p<0.01$, and ${ }^{* * *} p<0.001$ versus baseline values (2-way ANOVA with Bonferroni's post test) 
Table 1. RT-PCR analysis of PK2, PK2L, PKR1, and IL-1 $\beta$ gene expression in inflamed paws of CFA-treated mice compared with gene expression in contralateral noninflamed paws

\begin{tabular}{lccllll}
\hline & \multicolumn{2}{l}{ Wild-type mice } & & \multicolumn{2}{l}{ pkr1-null mice } & \\
\cline { 2 - 3 } & Inflamed contralateral & & & & Inflamed contralateral & \\
\hline PK2 & $19.8 \pm 4.7$ & $3.6 \pm 0.7$ & & $2.9 \pm 1.8$ & $0.5 \pm 0.2$ & $<0.05$ \\
PK2L & $34.1 \pm 4.8$ & $0.9 \pm 0,3$ & & $6.5 \pm 3.2$ & $0.1 \pm 0.1$ & $<0.01$ \\
PKR1 & $18.3 \pm 2.5$ & $1.6 \pm 0.6$ & & & \\
IL-1 $\beta$ & $192.6 \pm 57.7$ & $3.9 \pm 1.4$ & & $85.0 \pm 30.1$ & $4.3 \pm 2.1$ & $>0.5$ \\
\hline
\end{tabular}

Gene expression normalized to 165 ribosomal RNA.

p, Wild-type inflamed paws versus pkr1-null inflamed paws.

significant within the noxious temperature range from 46 to $50^{\circ} \mathrm{C}$, the operating range of C-polymodal nociceptors and the vanilloid channel TRPV1 (Le Bars et al., 2001; Tominaga and Tominaga, 2005). The impaired writhing response to intraperitoneal acetic acid in pkr1-null mice closely resembles that observed after pretreatment of wild-type mice with TRPV1 antagonists (Ikeda et al., 2001; Rigoni et al., 2003). Positive co-operation between PKRs and TRPV1 activation is also supported by the findings that Bv8 sensitizes primary afferent nociceptors to capsaicin and dramatically increases capsaicin-evoked specific currents in DRG neurons (Vellani et al., 2006).

Our results therefore show a novel example of TRPV1/GPCR interactions in nociceptive pathways. Heterologous sensitization of TRPV1 channel by G-protein-coupled receptors is now recognized as a mechanism by which the vanilloid channel opens even at temperatures $<40^{\circ} \mathrm{C}$, producing thermal hyperalgesia or allodynia (Tominaga and Tominaga, 2005). An important feature of TRPV1 regulation concerns the cellular signaling pathways through which G-protein-coupled receptors sensitize TRPV1 to its chemical and physical stimuli. These signaling pathways appear to involve phosphorylation by kinases including protein kinase A (PKA), PKC, $\mathrm{Ca}^{2+} / \mathrm{CaM}$-dependent kinase II or Src kinase (Tominaga and Tominaga, 2005) and phosphatidylinositol 3-kinase (Zhuang et al., 2004). Prostaglandins released in response to tissue injury and inflammation sensitize TRPV1 by activating their G-protein-coupled prostanoid receptors EP1 and IP (Moriyama et al., 2005) through a PKA-dependent pathway (Pitchford and Levine, 1991; Lopshire and Nicol, 1998; Rathee et al., 2002). Activation of the group I metabotropic glutamate receptors mGlu1 and mGlu5 potentiates capsaicin responses in mouse sensory neurons by the phospholipase C-prostanoidPKA pathway (Hu et al., 2002). Extracellular ATP and bradykinin have been reported to enhance TRPV1 responses through metabotropic $\mathrm{P}_{2} \mathrm{Y}_{2}$ and $\mathrm{B}_{2}$ receptors in a $\mathrm{PKC}$-dependent manner in both a heterologous expression system and native DRG neurons (Tominaga et al., 2001; Sugiura et al., 2002). A positive co-operativity in thermal nociception, closely resembling that of PKR1/TRPV1, is the recently described interaction between the CCR1 receptor of the proinflammatory chemokine CCL3 and TRPV1 (Zhang et al., 2005). CCR1 is coexpressed with TRPV1 in DRG small-diameter neurons, and its agonist CCL3 potentiates capsaicin responses both in whole animals and in DRG cultures in a PKC-dependent manner.

Although the molecular mechanism by which Bv8 and prokineticins sensitize TRPV1 to vanilloid agonists, heat, and protons remains to be elucidated, we can hypothesize that PKRs transduce the sensitizing signal through kinasedependent signaling pathways or through the release of nociceptive mediators, which in turn activate kinase signaling throughout their receptors. In a recent study, Vellani et al. (2006) demonstrated that in DRG primary cultures, nanomo- lar concentrations of Bv8 caused the $\varepsilon$ isoform of PKC to translocate from cytoplasm to the neuronal cell membrane and the $\mathrm{PKC} \varepsilon$-selective antagonist RO318221 inhibited the Bv8-induced sensitization to capsaicin in isolated DRG neurons. These results show that PKC plays a major role in sensitization caused by Bv8, although other cellular signaling pathways may be involved. The specificity of the PKR1/TRPV1 interaction is also suggested by the normal bradykinin- and PGE2-induced sensitization to thermal stimuli in WT and pkr1-null mice, indicating that no interaction took place between PGE2 and bradykinin GPCRs and PKR1GPCR. However, we cannot exclude that PGE2, bradykinin, and other nociceptive mediators participate in the Bv8-prokineticin signaling pathway in the downstream of PKR1 for sensitization of TRPV1.

In the present study, we noted that disruption of the PKR1 gene did not contribute equally to modulation of all forms of nociceptive response to heat. Although contact heat applied to the hindpaws and immersion of the tail in hot water disclosed a large nociceptive deficit in PKR1-null mice, the paw- and tail-withdrawal latency to radiant heat (Hargreaves' test and tail-flick test) in PKR1-null mice almost matched that of wildtype mice. Under baseline conditions, paw-withdrawal latency to hot water immersion was also comparable between the two genotypes but differed significantly after paw inflammation in each genotype. These differences in the thermal nociceptive threshold of PKR1-null mice may be only partially explained by our experimental paradigms. Because histologically and functionally distinct nociceptor subtypes innervate different anatomical sites, and because the physiological variables used differ, the applied noxious stimuli probably recruit distinct nociceptor subpopulations. These response differences may also reflect the fact that PKR1 may interact with receptors and ion channels other than TRPV1. Moreover, PKR2, which is expressed by DRG neurons different from those expressing PKR1 and is expressed normally by PKR1-null mice, could participate in specific pain conditions. Our present experiments with mustard oil in pkr1-null mice, as well as previous experiments on DRG neuronal cultures (Vellani et al., 2006), demonstrated that PKR activation potentiated mustard oilinduced nociceptive responses to heat and that, in DRG neuronal culture, responses to Bv8 interacted with and were colocalized with responses to mustard oil, an activator of the TRPA1 channel, which, like TRPV1, is involved in nociception (Tominaga and Caterina, 2004). Concerning the hypothesized nociceptive role of PKR2, we found that tactile allodynia was equally evoked by Bv8 in wild-type mice and PKR1-null mice, suggesting a possible role of PKR2 receptor in nociceptor sensitization to punctate stimuli.

pkr1-null mice exhibited impaired development of hyperalgesia after inflammatory injury, namely that elicited by mustard oil or CFA, suggesting the importance of the PKR1 receptor as a target for the treatment of both acute and chronic inflammatory pain. Mammalian PK1 and PK2, orthologs of amphibian Bv8, have been identified as selective peptide agonists of PKR1, but no PK1 or PK2 transcript could be detected in DRG and spinal cord of rats and mice. In previous studies (Lattanzi et al., 2001), we showed that PK2 is highly expressed by granulocytes in two isoforms (PK2 and PK2L) and that 
granulocyte-derived PK2 is a potent pronociceptive agent. The present data show that CFA-induced chronic inflammation strongly increases PK2 expression in mouse paw skin. Bv8 and prokineticins activate the prokineticin receptors of monocytes, macrophages, and dendritic cells, eliciting chemotaxis and releasing inflammatory and pronociceptive cytokines (Dorsch et al., 2005; Martucci et al., 2006), and the present study indicates that the pkr1 gene deletion reduces PK2 expression in inflamed skin. Given the role of the PKR1 receptor in setting the nociceptor threshold to noxious stimuli and triggering the release of inflammatory cytokines, we propose that this receptor plays a pivotal role in initiating or maintaining inflammatory pain.

These findings support a model in which prokineticins released within inflamed tissues augment nociceptor responsiveness by acting on PKR1. Although antagonists of the PKR1 receptor are not readily available, recent studies have identified some peptide antagonists (Bullock et al., 2004; Negri et al., 2005). These molecules are currently being evaluated and may represent a novel approach to the development of therapeutics for inflammatory pain conditions.

\section{References}

Akopian AN, Sivilotti L, Wood JN (1996) A tetrodotoxin-resistant voltagegated sodium channel expressed by sensory neurons. Nature 379:257-262.

Angerer LM, Cox KH, Angerer RC (1987) Demonstration of tissue-specific gene expression by in situ hybridization. Methods Enzymol 152:649-661.

Bullock CM, Li JD, Zhou QY (2004) Structural determinants required for the bioactivities of prokineticins and identification of prokineticin receptor antagonists. Mol Pharmacol 65:582-588.

Caterina MJ, Schumacher MA, Tominaga M, Rosen TA, Levine JD, Julius D (1997) The capsaicin receptor: a heat-activated ion channel in the pain pathway. Nature 389:816-824.

Caterina MJ, Leffler A, Malmberg AB, Martin WJ, Trafton J, Petersen-Zeitz KR, Koltzenburg M, Basbaum AI, Julius D (2000) Impaired nociception and pain sensation in mice lacking the capsaicin receptor. Science 288:306-313

Chaplan SR, Bach FW, Pogrel JW, Chung JM, Yaksh TL (1994) Quantitative assessment of tactile allodynia in the rat paw. J Neurosci Methods 53:55-63.

Chen CC, Akopian AN, Sivilotti L, Colquhoun D, Burnstock G, Wood JN (1995) A P2X purinoceptor expressed by a subset of sensory neurons. Nature 377:428-431.

Chessel IP, HatcherJP, Bountra C, Michel AD, Huges JP, Green P, Egerton J, Murfin M, Richardson J, Peck WL, Grahames CBA, Casula MA, Yiangou Y, Birch R, Anand P, Buell GN (2005) Disruption of the P2X7 purinoceptor gene abolishes chronic inflammatory and neuropathic pain. Pain 114:386-396.

Dai Y, Moriyama T, Higashi T, Togashi K, Kobayashi K, Yamanaka H, Tominaga M, Noguchi K (2004) Proteinase-activated receptor 2-mediated potentiation of transient receptor potential vanilloid subfamily 1 activity reveals a mechanism for proteinase-induced inflammatory pain. J Neurosci 24:4293-4299.

D'Amour FE, Smith DL (1941) Method for determining loss of pain sensation. J Pharmacol Exp Ther 72:74-79.

Dib-Hajj S, Black JA, Cummins TR, Waxman SG (2002) NaN/Nav1.9: a sodium channel with unique properties. Trends Neurosci 25:253-259.

Dorsch M, Qiu Y, Soler D, Frank N, Duong T, Goodearl A, O’Neil S, Lora J, Fraser CC (2005) PK1/EG-VEGF induces monocyte differentiation and activation. J Leukoc Biol 78:426-434.

Ferreira J, da Silva GL, Calixto JB (2004) Contribution of vanilloid receptors to the overt nociception induced by $\mathrm{B} 2$ kinin receptor activation in mice. Br J Pharmacol 141:787-794.

Hargreaves K, Dubner R, Brown F, Flores C, Joris J (1988) A new and sensitive method for measuring thermal nociception in cutaneous hyperalgesia. Pain 32:77-88.

Hu HJ, Bhave G, Gereau 4th RW (2002) Prostaglandin and protein kinase A-dependent modulation of vanilloid receptor function by metabotropic glutamate receptor 5: potential mechanism for thermal hyperalgesia. J Neurosci 22:7444-7452.

Ikeda Y, Ueno A, Naraba H, Oh-ishi S (2001) Involvement of vanilloid receptor VR1 and prostanoids in the acid-induced writhing responses of mice. Life Sci 69:2911-2919.

Koster R, Anderson M, de Beer EJ （1959） Acetic acid for analgesic screening. Fed Proc 18:412-414.

Lattanzi R, Giannini E, Melchiorri P, Negri L (2001) Pharmacology of Bv8: a new peptide from amphibian skin. Br J Pharmacol 133:45P.

Le Bars D, Gozariu M, Cadden SW (2001) Animal models of nociception. Pharmacol Rev 53:597-652.

LeCouter J, Kowalski J, Foster J, Hass P, Zhang Z, Dillard-Telm L, Frantz G, Rangell L, DeGuzman L, Keller GA, Peale F, Gurney A, Hillan KJ, Ferrara N (2001) Identification of an angiogenic mitogen selective for endocrine gland endothelium. Nature 412:877-884.

Lewis C, Neidhart S, Holy C, North RA, Buell G, Surprenant A (1995) Coexpression of $\mathrm{P} 2 \mathrm{X} 2$ and $\mathrm{P} 2 \mathrm{X} 3$ receptor subunits can account for ATPgated currents in sensory neurons. Nature 377:432-435.

Li M, Bullock CM, Knauer DJ, Ehlert FJ, Zhou QY (2001) Identification of two prokineticin cDNAs: recombinant proteins potently contract gastrointestinal smooth muscle. Mol Pharmacol 59:692-698.

Lin DCH, Bullock CM, Ehlert FJ, Chen JL, Thian H, Zhou QY (2002) Identification and molecular characterization of two closely related G-protein coupled receptors activated by prokineticins/EG-VEGF. J Biol Chem 277:19276-19280.

Lopshire JC, Nicol GD (1998) The cAMP transduction cascade mediates the prostaglandin E2 enhancement of the capsaicin-elicited current in rat sensory neurons: whole-cell and single-channel studies. J Neurosci 18:6081-6092.

Martucci C, Franchi S, Giannini E, Tian H, Melchiorri P, Negri L, Sacerdote P (2006) Bv8, the amphibian homologue of the mammalian prokineticins, induces a proinflammatory phenotype of mouse macrophages. Br J Pharmacol 147:225-234.

McMahon SB, Bennet DLH, Bevan S (2006) Inflammatory mediators and modulators of pain. In: Wall and Melzack's textbook of pain (McMahon SB, Koltzenburg M, eds), pp 49-72. London: Elsevier Churchill Livingstone.

Mollay C, Wechselberger C, Mignogna G, Negri L, Melchiorri P, Barra D, Kreil G (1999) Bv8, a small protein from frog skin and its homolog from snake venom induce hyperalgesia in rats. Eur J Pharmacol 374:189-196.

Moriyama T, Higashi T, Togashi K, Iida T, Segi E, Sugimoto Y, Tominaga T, Narumiya S, Tominaga M (2005) Sensitization of TRPV1 by EP1 and IP reveals peripheral nociceptive mechanism of prostaglandins. Mol Pain $1: 3-12$.

Negri L, Lattanzi R, Giannini E, Metere A, Colucci M, Barra D, Kreil G, Melchiorri P (2002) Nociceptive sensitisation by the secretory protein Bv8. Br J Pharmacol 137:1147-1154.

Negri L, Lattanzi R, Giannini E, Colucci M, Mignogna G, Barra D, Grohovaz F, Codazzi F, Kaiser A, Kreil G, Melchiorri P (2005) Biological activities of Bv8 analogues. Br J Pharmacol 146:625-632.

Pesquero JB, Lindsey CJ, Zeh K, Paiva AC, Ganten D, Bader M (1994) Molecular structure and expression of rat bradykinin B2 receptor gene. Evidence for alternative splicing. J Biol Chem 269:26920-26925.

Pitchford S, Levine JD (1991) Prostaglandins sensitize nociceptors in cell culture. Neurosci Lett 132:105-108.

Rathee PK, Distler C, Obreja O, Neuhuber W, Wang GK, Wang SY, Nau C, Kress M (2002) PKA/AKAP/VR-1 module: a common link of Gsmediated signaling to thermal hyperalgesia. J Neurosci 22:4740-4745.

Rigoni M, Trevisani M, Gazzieri D, Nadaletto R, Tognetto M, Creminon C, Davis JB, Campi B, Amadesi S, Geppetti P, Harrison S (2003) Neurogenic responses mediated by vanilloid receptor-1 (TRPV1) are blocked by the high affinity antagonist, iodo-resiniferatoxin. Br J Pharmacol 138:977-985.

Shi TJ, Hua XY, Lu X, Malkmus S, Kinney J, Holmberg K, Wirz S, Ceccatelli S, Yaksh T, Bartfai T, Hokfelt T (2006) Sensory neuronal phenotype in galanin receptor 2 knockout mice: focus on dorsal root ganglion neurone development and pain behaviour. Eur J Neurosci 23:627-636.

Sugiura T, Tominaga M, Katsuya H, Mizumura K (2002) Bradykinin lowers the threshold temperature for heat activation of vanilloid receptor 1 . J Neurophysiol 88:544-548.

Tominaga M, Caterina MJ (2004) Thermosensation and pain. J Neurobiol 61:3-12. 
Tominaga M, Tominaga T (2005) Structure and function of TRPV1. Pflügers Arch 451:143-150.

Tominaga M, Wada M, Masu M (2001) Potentiation of capsaicin receptor activity by metabotropic ATP receptors as possible mechanism for ATPevoked pain and hyperalgesia. Proc Natl Acad Sci USA 98:6951-6956.

Vellani V, Mapplebeck S, Moriondo A, Davis JB, McNaughton PA (2001) Protein kinase $\mathrm{C}$ activation potentiates gating of the vanilloid receptor VR1 by capsaicin, protons, heat and anandamide. J Physiol (Lond) 534:813-825.

Vellani V, Colucci M, Lattanzi R, Giannini E, Negri L, Melchiorri P, McNaughton P (2006) Sensitization of TRPV1 by the prokineticin receptor agonist Bv8. J Neurosci 26:5109-5116.

Waldmann R, Champigny G, Bassilana F, Heurteaux C, Lazdunski M (1997)
A proton-gated cation channel involved in acid-sensing. Nature 386:173-177.

Wechselberger C, Puglisi R, Engel E, Lepperdinger G, Boitani C, Kreil G (1999) The mammalian homologues of frog Bv8 are mainly expressed in spermatocytes. FEBS Lett 462:177-181.

Zhang N, Inan S, Cowan A, Sun R, Wang JM, Rogers TJ, Caterina M, Oppenheim JJ (2005) A proinflammatory chemokine, CCL3, sensitizes the heat- and capsaicin-gated ion channel TRPV1. Proc Natl Acad Sci USA 102:4536-4541.

Zhuang ZY, Xu H, Clapham DE, Ji RR (2004) Phosphatidylinositol 3-kinase activates ERK in primary sensory neurons and mediates inflammatory heat hyperalgesia through TRPV1 sensitization. J Neurosci 24:8300-8309. 